\title{
INVESTIGATING THE INFLUENCE OF SERVICE TRAINING, REWARD SYSTEM AND EMPOWERMENT ON JOB SATISFACTION AND ORGANIZATIONAL COMMITMENT OF THE EMPLOYEES OF ILAM'S TELECOMMUNICATIONS COMPANY
}

\author{
Mohammad Taban ${ }^{1}$, Seidmehdi Veiseh ${ }^{2}$ and Yasan allah Poorashraf ${ }^{3}$ \\ ${ }^{1}$ Assistant Professor of Management Department, University of Ilam \\ taab1351@ut.ac.ir \\ ${ }^{2}$ Assistant Professor of Mathematic Department, University of Ilam \\ Amir 7912000@yahoo.com \\ ${ }^{3}$ Associate Professor of Management Department, University of Ilam \\ yasan_ashraf@yahoo.com
}

\begin{abstract}
The current study focuses on the investigation of the relationship between variables training, reward, empowerment and job satisfaction of the employees and the influence of job satisfaction on the organizational commitment. In so doing, the relationship between super pattern variables was considered on the basis of some theoretical principles. This is a correlative study in which the path analysis model is used, because it is possible to investigate direct and indirect paths through such model. Population included all employees of Ilam's telecommunications company among whom 190 ones were selected as the sample by use of randomized sampling model. Data was gathered using five standard questionnaires. The reliability and admissibility of the questionnaires was evaluated by use of Coronbach's $\alpha$ and explorative factor analysis. In order to test the available pattern, the path analysis technique was used. Results show that there is a meaningful relationship between the above mentioned variables.
\end{abstract}

\section{KEYWORDS}

Training, reward, empowerment, job satisfaction, organizational commitment, Telecommunications Company

\section{INTRODUCTION}

During the past decades, an organization was mainly evaluated on the basis of factors such as financial resources and equipment. But today, the main comparative capitals of the organizations are the skilled and educated persons who are thoroughly proficient in the technological David C. Wyld et al. (Eds) : CCSEA, CLOUD, DKMP, SEA, SIPRO - 2016 pp. 147-156, 2016. @ CS \& IT-CSCP 2016

DOI : $10.5121 / \mathrm{csit} .2016 .60213$ 
knowledge. In comparison to 1982, the big organizations are the owners of $\% 15$ of tangible and $\% 85$ of intangible assets of the world ( Azarhoosh, 2005). One of the main mental disturbances of the managers is productivity and the factors affect on. Althin (2005) believes that productivity of each organization depends mainly on its human resources. The Japan's productivity association has declared that the productivity of each organization is affected by the factors such as empowerment of the employees, training, participative management, justice and just distribution (Steiner, 1997). It is hypothesized that there is a direct relationship between effective use of human resource and increase of organizational commitment (Khaki, 2010). Under the influence of not taking into consideration the human resource management of the organization, the employees' loyalty and commitment is decreased. Telecommunications Company is also affected by the human resource capital. In this regard, it is important to obviate the employees' problems and motivate them in order to increase the quality and performance of the company. In this study, the organizational commitment of the employees of Telecommunications Company is regarded as the dependent variable affected by factors such as training, reward, and empowerment and job satisfaction.

\section{STATEMENT OF ISSUE}

Today, the organizations should be managed in a comparative environment. In such conditions, the mangers have no suitable opportunity to managing the employees who are charged with the most of duties. The employees are able to perform delivered duties when they enjoy suitable skills, knowledge and abilities. By empowerment of the employees, we mean a set of systems, approaches and measures used for increasing productivity of the organization and human resources (Carter, 2001). The word "empowerment" is referred to the person's knowledge from $\mathrm{him} /$ her self. Empowerment is related to the factors such as organizational environment, the relationship between employees, manager and coworkers (Moye, \& Henkin, 2006).. It is defined as one of the main management procedures for making decisions (Melham, 2004). Empowerment of the employees refers to when the employees can develop their abilities and knowledge in order to enhance personal and organizational goals. In reality, empowerment is a process through which the internal opinions of the persons are changed (Vtn, \&Cameron, 1991). Reviewing the literature, Karakoc (2009) argues that the employees' empowerment is influenced by some factors including inclination for developing, having the art of criticism, acceptance of change, high self - confidence, dynamic structure, evaluation of performance, feedback, reward, support, training, communications, motivation, encouragement, participative culture, flexibility, freedom of speech, information sharing and management confidence. In order to perform empowerment, the managers should equip the employees with needed information and training. The managers should become sure that the employees receive continual training (Senate et al, 2007). Training is aimed to solve the organization's problem, create necessary changes, increase the knowledge of new employed staff, share information and develop skills (Berge, 2008). Moreover, it is possible to solve some problems for the employees by training (Hosseinzadeh\&Barziagar, 2004).

On the other hand, Rand Lip states that the mangers have a tendency toward the empowerment of the employees. Moreover, the employees suppose them valuable and have more participation in working. Empowerment entails positive results including workforce replacement, productivity improvement and increase of organizational commitment and motivation (Rasouly, 2005). Furthermore, empowerment leads to increase the performance of various units of the organization, the mutual respect of the employees and the emphasis on how the problems are 
solved (Klug, 1998). Job satisfaction is one of the main consequences of empowerment. It has been said (Tomas\&lighthouse) that high self-confidence can increase the job satisfaction.

Moreover, freedom of action can also lead to the increase of job satisfaction. Telecommunications Company is one of the main companies of each country. Therefore, investigation of factors such as job satisfaction and organizational commitment of the employees is of great importance. Moreover, it is important to recognize the variables having influence on the employees' job satisfaction and commitment, because productivity of Telecommunications Company is affected by such variables.

\section{RESEARCH GOALS}

This study aims to investigate the relation between training, reward, empowerment and job satisfaction of the employees and the influence of job satisfaction on the organizational commitment. In this regard, the followings should be mentioned:

1. The relationship between training and job satisfaction of the employees of Ilam's telecommunication company

2. The relationship between reward system and job satisfaction of the employees of Ilam's telecommunication company.

3. The relationship between empowerment and job satisfaction of the employees of Ilam's telecommunication company.

4. The relationship between job satisfaction and organizational commitment of the employees of Ilam's telecommunication company.

\section{RESEARCH HYPOTHESIS}

Hypothesis 1: there is a positive and meaningful relationship between training and job satisfaction of the employees of Ilam'stele communications company.

Hypothesis 2: There is a positive and meaningful relationship between reward and job satisfaction of the employees of Ilam's telecommunication company.

Hypothesis 3: there is a positive and meaningful relationship between empowerment and job satisfaction of the employees of Ilam's telecommunications company.

Hypothesis 4: there is a positive and meaningful relationship between job satisfaction and organizational commitment of the employees of Ilam's telecommunications company.

\section{METHOD}

Since the relationship between the variables is analyzed on the basis of research goal, this is a correlational - descriptive research. This study is aimed to recognize the cause and effect patterns 
of the variables. This approach allows the researchers to analyze the possible relationship between the variables of the study. Data was analyzed by use of structural equations modeling.

\subsection{Population}

Populations included all employees of Ilam's telecommunication company in 2013-2014. They were selected by use of simple randomized sampling method.

\subsection{Sample}

Determination of sample of the research is one of the main problems to which the authors are always faced. It has been decided to consider 8 persons for each parameter. Therefore, the sample of the research includes 200 employees.

\section{FINDINGS}

Table 1: correlation matrix of the research variables

\begin{tabular}{|l|l|l|l|l|}
\hline & 1 & & & \\
\hline Reward & $/ 23$ & 1 & & \\
\hline Empowerment & $/ 22$ & $/ 37$ & 1 & \\
\hline Job satisfaction & $/ 28$ & $/ 38$ & $/ 71$ & 1 \\
\hline $\begin{array}{l}\text { Organizational } \\
\text { commitment }\end{array}$ & $/ 27$ & $/ 33$ & $/ 52$ & $/ 61$ \\
\hline
\end{tabular}

Correlation matrix is used for examining the linear relationship between the variables. The figures varied from -1 to +1 and the high degree of the correlation reveals the ratio of the relationship between the variables. Correlation matrix related to the variables is seen in the above table.

As shown in the above table, there is a meaningful correlation between the variables. This is, therefore, to say that there is a linear relationship between the variables. Moreover, the available coefficients are between $\% 20$ and \%90; it means that there is no meaningful relationship between the variables.

Table 2: The HomographSmirnoff's test used for investigating normal condition of the variables

\begin{tabular}{|c|c|c|c|c|c|c|}
\hline \multicolumn{2}{|c|}{} & $\begin{array}{c}\text { Compensation } \\
\text { of services }\end{array}$ & Reward & $\begin{array}{c}\text { Empowermen } \\
\mathbf{t}\end{array}$ & $\begin{array}{c}\text { Organizational } \\
\text { commitment }\end{array}$ & Job satisfaction \\
\hline $\begin{array}{c}\text { Normal } \\
\text { parameters }\end{array}$ & Average & 3.23 & 3.23 & 3.22 & 3.19 & 3.31 \\
\cline { 2 - 7 } & $\begin{array}{c}\text { Standard } \\
\text { deviation }\end{array}$ & 0.344 & 0.507 & 0.502 & 0.382 & 0.582 \\
\hline \multicolumn{2}{|c|}{$\begin{array}{c}\text { Clomograph- } \\
\text { Simronoph's factor }\end{array}$} & 2.91 & 1.40 & 2.77 & 1.73 & 2.64 \\
\hline \multicolumn{2}{|c|}{ Meaningful level } & 0.098 & 0.089 & 0.077 & 0.051 & 0.118 \\
\hline
\end{tabular}


Table above shows that data distribution is normal $(\mathrm{p}>/ 5)$ and it is possible to ignore the linear correlation between the variables. Regarding the hypothesis of path analysis, the following figure is presented for hypothesis test.

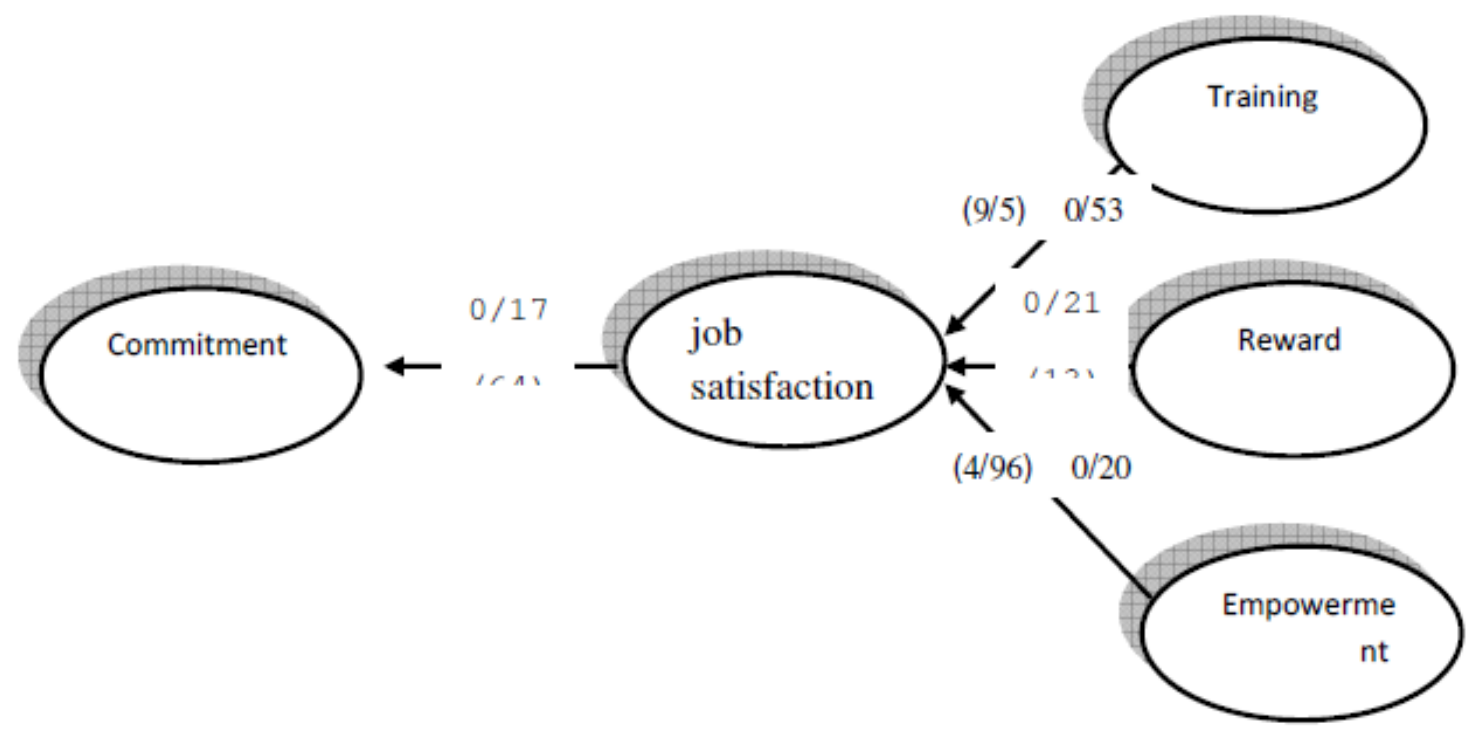

Figure 4-1: hypothesized model after fitting

As seen in the above figure, all paths are statistically meaningful. These paths include: (a) the path of influence of training on job satisfaction $(\beta=/ 53, t=9 / 5)$; (b) the path of influence of reward on job satisfaction $(\beta=/ 21, t=5 / 13)$; ( c) the path of influence of empowerment on job satisfaction $(\beta=/ 20, t=4 / 96)$ and $(d)$ the path of the influence of job satisfaction on organizational commitment $(\beta=/ 17, t=3 / 64)$. Moreover, all parameters show the positive and meaningful effect of the variables.

\section{FINAL MODEL OF THE RESEARCH}

a) Direct, indirect and total affect of exogenous variable on the hidden endogenous variables

In final model of the research, all direct paths of influence of hidden exogenous variables on the hidden exogenous variables on the hidden endogenous ones are investigated. In this regard, it is necessary to examine direct influence of hidden exogenous variables (training, reward and empowerment) on the hidden endogenous variables (job satisfaction and organizational commitment). The parameters related to the direct influence of exogenous variables are seen in the table below.

Table 3: Parameters related to the direct / indirect influences of hidden exogenous variable on the hidden endogenous ones

\begin{tabular}{|l|l|l|l|l|}
\hline $\begin{array}{l}\text { Hidden } \\
\text { exogenous }\end{array}$ & Effects & $\begin{array}{l}\text { Hidden } \\
\text { endogenous } / \\
\text { parameters }\end{array}$ & Job satisfaction & $\begin{array}{l}\text { Organizational } \\
\text { commitment }\end{array}$ \\
\hline Training & $\begin{array}{l}\text { Direct } \\
\text { effectiveness }\end{array}$ & $\begin{array}{l}\text { Parameter b } \\
\text { estimation }\end{array}$ & 0.29 & - \\
\hline
\end{tabular}




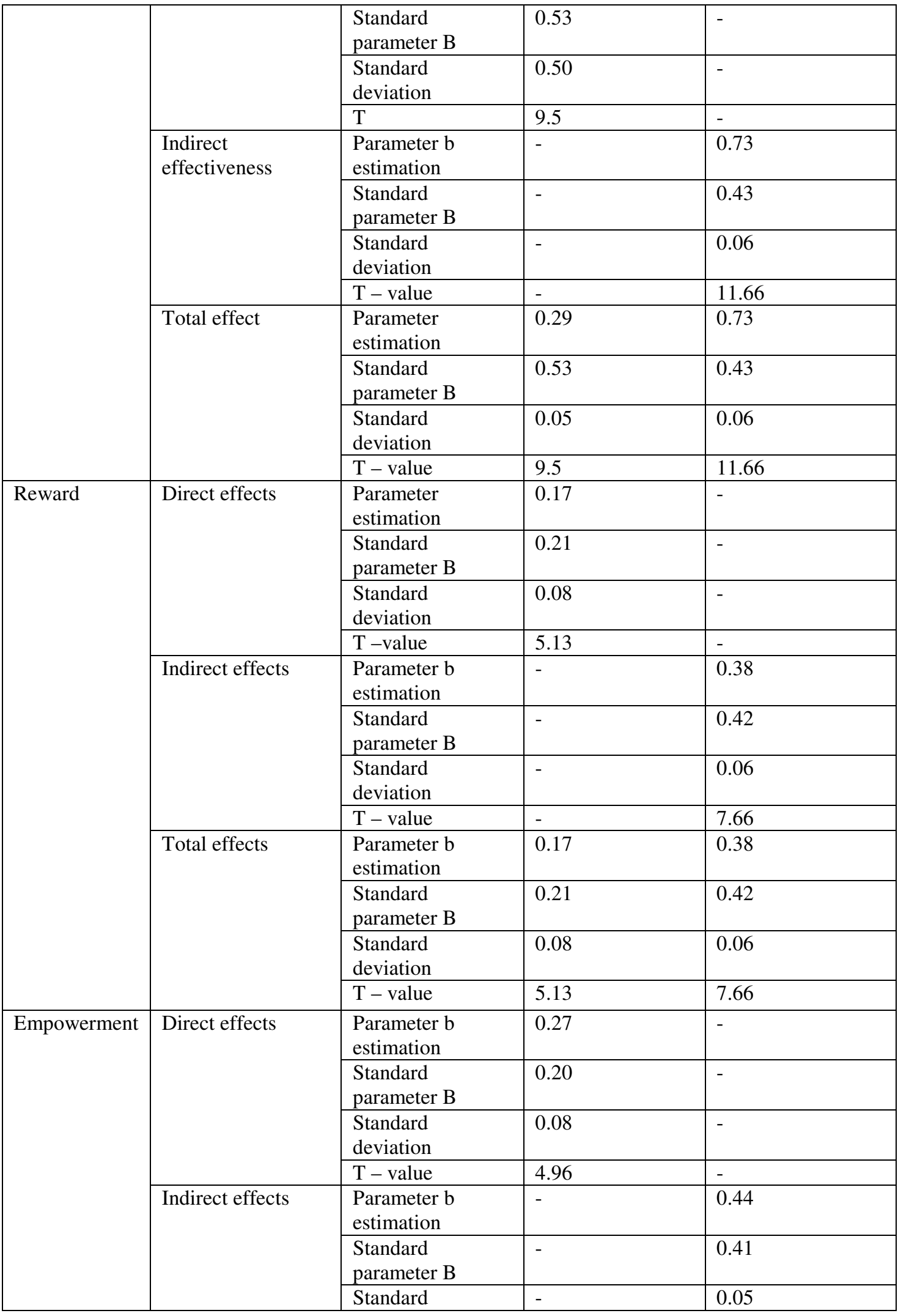




\begin{tabular}{|l|l|l|l|l|}
\hline & deviation & & \\
\cline { 3 - 5 } & T - value & - & 8.90 \\
\cline { 3 - 5 } & Total effects & $\begin{array}{l}\text { Parameter b } \\
\text { estimation }\end{array}$ & 0.27 & 0.44 \\
\cline { 3 - 5 } & $\begin{array}{l}\text { Standard } \\
\text { parameter B }\end{array}$ & 0.20 & 0.41 \\
\cline { 3 - 5 } & $\begin{array}{l}\text { Standard } \\
\text { deviation }\end{array}$ & 0.08 & 0.05 \\
\hline & T-value & 4.96 & 8.90 \\
\hline
\end{tabular}

As seen above, the $\mathrm{t}$ - value related to the all direct influences of hidden exogenous variables on endogenous variables is 2 and it is statistically meaningful. The biggest figure is related to the direct influence of training on job satisfaction $(\beta=/ 53)$ and the weakest is related to the influence of empowerment on job satisfaction $(\beta=/ 20)$.

Finally, total affect include the sum of direct and indirect affects of the variables. Moreover, all $t$ - values are equal to $\% 5$. The most powerful influences are the influence of training on job satisfaction $(\beta=/ 53)$. And the influence of training on organizational commitment $(\beta=/ 42)$.

b) Direct influence of hidden endogenous variables on other endogenous variables

Table 4: parameters related to the direct influences of hidden endogenous variable (Y)

\begin{tabular}{|l|l|l|l|l|l|}
\hline $\begin{array}{l}\text { Hidden } \\
\text { endogenous }\end{array}$ & $\begin{array}{l}\text { Hidden } \\
\text { endogenous }\end{array}$ & $\begin{array}{l}\text { Parameter B } \\
\text { estimation }\end{array}$ & $\begin{array}{l}\text { Standard } \\
\text { parameter B }\end{array}$ & $\begin{array}{l}\text { Standard } \\
\text { deviation }\end{array}$ & $\begin{array}{l}\text { T - } \\
\text { value }\end{array}$ \\
\hline Job satisfaction & $\begin{array}{l}\text { Organizational } \\
\text { commitment }\end{array}$ & 0.13 & 0.17 & 0.04 & 3.64 \\
\hline $\mathrm{P}<\% 5$ & & & \\
\hline
\end{tabular}

Findings show that the $\mathrm{t}$ - values relative to the relation between job satisfaction and organizational commitment are meaningful. Therefore, the endogenous variable job satisfaction influences directly on the variable organizational commitment. From the above table, $\beta=/ 17$ and its error degree is $\% 4$.

c) Total influence of hidden endogenous variables on each other

Parameters related to the total influence of hidden endogenous variable job satisfaction on the other variable organizational commitment are shown in the table 5

\begin{tabular}{|l|l|l|l|l|l|}
\hline $\begin{array}{l}\text { Hidden } \\
\text { endogenous }\end{array}$ & $\begin{array}{l}\text { Hidden } \\
\text { endogenous }\end{array}$ & $\begin{array}{l}\text { Parameter B } \\
\text { estimation }\end{array}$ & $\begin{array}{l}\text { Standard } \\
\text { parameter B }\end{array}$ & $\begin{array}{l}\text { Standard } \\
\text { deviation }\end{array}$ & T - value \\
\hline Job satisfaction & $\begin{array}{l}\text { Organizational } \\
\text { commitment }\end{array}$ & 0.13 & 0.17 & 0.04 & 3.64 \\
\hline $\mathrm{P}<\% 5$ & & & \\
\hline
\end{tabular}

Finding show that when $\mathrm{p}<\% 5$, the $\mathrm{t}-$ value related to the influence of job satisfaction on organizational commitment is meaningful. 
In reality, the total influence of the endogenous variable job satisfaction on organizational commitment is statistically meaningful, because $\beta=/ 17$ and error degree is $\% 4$.

d) The variance of hidden endogenous variables

After investigating the direct, indirect and total influences of the model, it is necessary to determine the variance of organizational commitment on the basis of endogenous and exogenous variables..

Table 6: the variance determined on the basis of hidden endogenous variables

\begin{tabular}{|l|l|l|}
\hline Anticipative variables & Anticipated variables & $\mathbf{R}^{\mathbf{2}}$ \\
\hline Training & Job satisfaction & 0.28 \\
\hline Training and job satisfaction & Organizational commitment & 0.46 \\
\hline Reward & Job satisfaction & 0.75 \\
\hline Reward and job satisfaction & Organizational commitment & 0.59 \\
\hline Empowerment & Satisfaction & 0.45 \\
\hline Empowerment and satisfaction & Organizational commitment & 0.25 \\
\hline
\end{tabular}

Due to the findings, the variable organizational commitment is mainly affected by the variables reward and job satisfaction $\left(\mathrm{R}^{2}=/ 59\right)$. This is to say that based on the final model of the research, the variance of educational development is determined by $\% 25$.

\section{DISCUSSION AND CONCLUSION}

Hypothesis 1: the variable training affects directly on job satisfaction of the employees of Ilam'stelecommunications company. Results showed that job satisfaction of the employees is directly affected by the training.

Since the improvement of job knowledge is one of the main feedbacks of training periods, it seems that job satisfaction of the employees of Telecommunications Company is mainly affected by training. The employees of an organization can perform their duties better when they receive training programs.

Hypothesis 2: reward system affects directly on job satisfaction of the employees.

From the results, it becomes clear that job satisfaction is directly and meaningfully affected by reward system. It is hypothesized that the employees of an organization put emphasize on factors such as salary, advancement, work identity, organizational procedures and work conditions. In this regard, the managers should prepare the fields of satisfaction of the employees, because there is a meaningful correlation between job satisfaction and the employees' effectiveness and mental health. In other words, the employees work better when they are supported by the organization. On the other hand, the organization's support has influence on the employees' self confidence.

Hypothesis 3: empowerment has direct and meaningful influence on the employees' job satisfaction.

Since $\beta=/ 20$ and $t-$ value $=4 / 96$, job satisfaction is meaningfully affected by empowerment. 
As mentioned before, empowerment is one of the modern approaches by which the employees are motivated to perform their duties better. It is argued that empowerment - based management increases the human resources' effectiveness. The managers should make clear the employees' responsibilities and objectives by making participative decisions. From organizational perspective, the human resources sector should make developmental programs available to the employees. In other words, the managers should have control over the employees' performance and cause them to experience the feeling of joy and respect. Moreover, organizational productivity and commitment is increased by moral values of the staff, including confidence and validity.

Hypothesis 4: job satisfaction affects directly and meaningfully on the employees' organizational commitment.

Evidences show that organizational commitment of the employees is directly affected by job satisfaction. Moreover, organizational dynamism depends on factors such as the presence of skilled and creative persons. The employees should be loyal to the organization. The loyalty of the employees causes more organizational development.

It is important to investigate the relationship between job satisfaction and organizational commitment as the two variables having influence on the development of organizational goals and the employees learning. The employees can help the organization to fulfill its objectives. Through being satisfied, the employees can help the organization to fulfill its goals. The employees of Telecommunications Company try to preserve their job opportunities because transfer of learning is impossible. Such behavior has negative influence on the relations between the employees and the managers. Therefore, the managers should allow the employees to participate in decision makings in order to stabilize their positions. They should make clear the employees' role in order to increase their affiliation and effectiveness.

\section{REFERENCES}

[1] Althin, L. (2005). Efficiency And Productivity of Employment Offices Employment: Evidence From Sweden,. International Journal of Manpower, 26(2), 196-206.

[2] Azarhosh, F (2005), Trends and new ideas in management, Proceedings of the Second Conference on Human Resource Development. Industry Development and Renovation Organization of Iran.

[3] Carter, M. (2001). Strategic planning in nonprofit or for profit organizations. from www.Strategic planning .com

[4] Karakoc, N. (2009). Employee Empowerment and Differentiation in Companies: A Literature Review and Research Agenda. Enterprise Risk Management, 1(2)

[5] Khaki, G. (2010). Approach to the research dissertation. Tehran, publishing reflection.

[6] Klagge,J(1998) The empowerment squeeze-views from the middle management position. Journal of Management Development, Vol 17. No 8. P 548-558.

[7] Hossein-Zadeh, D., Barzegar N. (2004), Learning processes in organizations. Islamic Azad University. Save 
[8] Moye, M. Henkin, A(2006) Exploring association between employee empowerment \& interpersonal trust in manager. Journal of Management Development. Vol 25. No 2. P 101-117.

[9] Melhem, $\mathrm{Y}(2004)$ The antecedents of customer-contact employees empowerment. Employee Relations, Vol 26. No 1.p 72-93

[10] Rasouli, R. (2005), examined the relationship between employee empowerment, job stress, job satisfaction and organizational commitment. Quarterly Message. No. 16-15. Pp. 194-165

[11] Seadat talab, A, Yasin, A. (2011). The relationship between quality of work life of faculty motivation and martyr Beheshti University in Tehran. National Conference on Higher Education Isfahan.

[12] Stainer, A. (1997). Logistic-a Productivity and Performance Perspective. Suuly Chan Management an International Journal, 2(4), 53-62.

[13] Thomas, K.W. and Velthouse, B.A. (1990). Cognitive elements of empowerment: an interpretive model of intrinsic task motivation"' Academy of Management Review, Vol. 15 No. 4, pp. 666-81

[14] Vtn, D. Cameron, K, (1999, empowerment and delegation, Translation: . Avry Yzdanyv Badroddin ,Management Education Research Institute. 